\title{
Expression of the HBZ and tax genes of HTLV-1in infective dermatitis associated with HTLV-I (IDH)
}

\author{
Everton S Batista ${ }^{1}$, Isabela Archanjo ${ }^{1}$, Kiyoshi Fukutani ${ }^{2}$, Maria deFatima P de Oliveira ${ }^{3}$, Achilea C Bittencourt ${ }^{4}$, \\ Lourdes Farre ${ }^{1 *}$
}

From 15th International Conference on Human Retroviruses: HTLV and Related Viruses

Leuven and Gembloux, Belgium. 5-8 June 2011

\section{Background}

Recent studies have shown that basic leucine zipper factor (HBZ) gene was transcribed in all adult HTLV-1 infected individuals examined, including ATL and HAM/TSP patients, whereas tax mRNA was only transcribed in a half of these groups. The amount of HBZ mRNA expression per provirus was higher than tax mRNA expression in HAM/TSP and adult asymptomatic carriers. Nevertheless, there are no data on HBZ and tax mRNA expression in child and adolescent carriers. The aim of this study was to quantify the HBZ and tax mRNA expression levels in infective dermatitis associated with HTLV-1 (IDH).

\section{Materials and methods}

RNA was extracted from PBMC of 31 patients with IDH and 8 adolescent asymptomatic carriers. The mRNA expression levels were quantified by real-time quantitative PCR. For HBZ gene, spliced (HBZ-SI) and nonspliced (HBZ) transcripts were analyzed.

\section{Results}

The HBZ mRNA expression levels were higher than the tax mRNA expression levels in patients with IDH and in the asymptomatic carriers, for both HBZ-SI $(p<0.0001$ and $\mathrm{p}=0.006$, respectively) and HBZ $(\mathrm{p}=0.0019$ and $\mathrm{p}=0.005)$ transcripts. The HBZ-SI mRNA load was greater than the expression of the HBZ transcript $(\mathrm{p}=0.0005)$ only in IDH patients. HBZ-SI and HBZ mRNA load positively correlated with tax mRNA load $(\mathrm{p}=0.0014, \mathrm{r}=0.548$ and $\mathrm{p}=0.0001, \mathrm{r}=0.640$; respectively $)$ in IDH patients but not in asymptomatic carriers. There

\footnotetext{
* Correspondence: Lfarre@bahia.fiocruz.br

'Laboratory of Experimental Pathology, CPQGM, FIOCRUZ, Salvador, Bahia, 40296710, Brazil

Full list of author information is available at the end of the article
}

was no correlation between the expression of these genes and proviral load in the two groups evaluated.

\section{Conclusion}

These findings suggest that expression of $\mathrm{HBZ}$ gene plays a role in early stages of HTLV-1 infection.

\section{Author details}

'Laboratory of Experimental Pathology, CPQGM, FIOCRUZ, Salvador, Bahia, 40296710, Brazil. 'Laboratory of Immunoparasitology, CPQGM, FIOCRUZ, Salvador, Bahia, 40296710, Brazil. ${ }^{3}$ Department of Internal Medicine, HUPES, Federal University of Bahia, Salvador, Bahia, 40296710, Brazil. ${ }^{4}$ Department of Pathology, HUPES, Federal University of Bahia, Salvador, Bahia, 40296710, Brazil.

Published: 6 June 2011

\section{doi:10.1186/1742-4690-8-S1-A252}

Cite this article as: Batista et al.: Expression of the HBZ and tax genes of HTLV-1 in infective dermatitis associated with HTLV-I (IDH). Retrovirology 2011 8(Suppl 1):A252.

\section{Submit your next manuscript to BioMed Central and take full advantage of: \\ - Convenient online submission \\ - Thorough peer review \\ - No space constraints or color figure charges \\ - Immediate publication on acceptance \\ - Inclusion in PubMed, CAS, Scopus and Google Scholar \\ - Research which is freely available for redistribution

